\title{
Tonsillectomy with BiZact: Impressions from four cases
}

\author{
BiZact ile tonsillektomi: Dört olgudan izlenimler \\ M. Mazhar Çelikoyar (D, Erkan Aktan (1) \\ Department of Otolaryngology, Istanbul Florence Nightingale Hospital, Istanbul, Turkey
}

\begin{abstract}
Tonsillectomy is a surgical technique of a long history. BiZact is one of the instruments developed lately for this surgery. In this article, we report our impressions on a four-year-old boy, a four-year-old girl, a 28-year-old male and a 35-year-old male patient who were performed tonsillectomy using BiZact. Uvular thermal injury was seen in one of the children, and one of the adults had a secondary hemorrhage on the postoperative fifth day. Given the relatively new introduction of BiZact into the tonsillectomy field, we wished to share our experience, although a very limited number of cases were studied.
\end{abstract}

Keywords: Chronic tonsillitis, hypertrophic tonsils, surgery, surgical technology, tonsillectomy.

Tonsillectomy is a well-defined surgical technique. In the first century BCE, Cornélio Celsus was the first to describe a complete tonsillectomy. The complete removal of tonsils was generally thought to stop until about the $16^{\text {th }}$ century when newer tools, such as the snare, were used. In 1909, tonsillectomy became a more common and safer procedure, when Cohen began to use ligature of bleeding vessels to control perioperative hemorrhage. ${ }^{[1]}$

Today, tonsillectomy is generally considered safe, but surgeons should be cognizant of potential complications and prepared to manage them. Postoperative hemorrhage usually responds to local measures or cautery while it can be life threatening. While anesthetic risks have declined with modern techniques, airway risks, aspiration, and pulmonary edema are still
$\ddot{O} Z$

Tonsillektomi uzun bir geçmişe sahip bir cerrahi tekniktir. Son

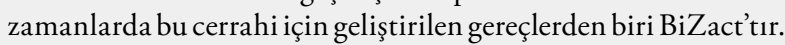
$\mathrm{Bu}$ yazıda, BiZact kullanılarak tonsillektomi uygulanan dört yaşında bir erkek, dört yaşında bir kız, 28 yaşında bir erkek ve 35 yaşında bir erkek hasta ile ilgili izlenimlerimiz bildirildi. Çocukların birinde uvulada termal zedelenme gözlendi ve bir erişkinde ameliyat sonrası beşinci günde ikincil kanama gelişti. Çalışılan olgu sayısı çok sınırlı olsa da BiZact'ın tonsillektomi alanında göreceli yeni olan kullanımını göz önünde bulundurarak deneyimimizi paylaşmak istedik.

Anahtar sözcükler: Kronik tonsillit, hipoertrofik tonsiller, cerrahi, cerrahi teknoloji, tonsillektomi.

possible. Operative complications include trauma to the teeth, larynx, pharyngeal wall (constrictor muscle or underlying arterial structures), or soft palate, as well as difficult intubation, laryngospasm, laryngeal edema, aspiration, respiratory compromise, endotracheal tube ignition, and cardiac arrest. ${ }^{[2]} \mathrm{A}$ mortality rate of $0.03 \%$ has been reported. ${ }^{[3]}$ Injury to nearby structures have been reported, including carotid artery injury, tongue swelling, altered taste, lip burn, eye injury, and fracture of the mandibular condyle. ${ }^{[3]}$ Nasopharyngeal valving may be altered by velopharyngeal incompetence or nasopharyngeal stenosis. ${ }^{[4]}$ Sore throat, otalgia, fever, dehydration, and uvular edema are more common postoperative complaints. ${ }^{[5]}$ Less common complications include atlantoaxial subluxation, post-obstructive pulmonary edema, mandible condyle fracture, infection, eustachian tube injury, and psychological trauma. ${ }^{[6,7]}$

Received: August 23, 2019 Accepted: November 11, 2019 Published online: February 07, 2020

Correspondence: M. Mazhar Çelikoyar, MD. Küçüksu Mah., Yalnız Selvi Cad., Çengelköy Mesa Evleri, B7 Blok, D: 1, Üsküdar, İstanbul, Türkiye. e-mail: mazhar.celikoyar@gmail.com 
Surgeons have tried various modifications of the surgical technique to overcome the morbidity associated with tonsillectomy. Cold dissections with knife, scissors, or snare were the traditional instruments for tonsillectomies; however, electrocautery dissection with its advantage of improved hemostasis has since replaced cold dissection techniques for most surgeons. ${ }^{[8]}$ The use of diathermy to achieve hemostasis after tonsillectomy was introduced in the 1960s and has become increasingly popular while it has been shown that patients undergoing tonsillectomy with diathermy have an increased rate of postoperative secondary hemorrhage compared with those who had dissection and hemostasis without diathermy. ${ }^{[9,10]}$

Despite these findings, according to Blanchford and Lowe, ${ }^{[11]}$ in a child under the age of three-four years, or one of particularly low weight (and hence low circulating blood volume), these considerations may lead surgeons to adopt the alternative hot technique for tonsillectomy. Use of bipolar diathermy for both dissection and hemostasis is recommended (with careful application of diathermy at the lowest effective setting). For tonsillectomy, many technologies and instruments were introduced to improve surgical techniques and decrease postoperative morbidity rates. Most of these instruments can be called "heat generating," such as potassium titanyl phosphate/holmium laser, carbon dioxide laser, argon plasma, ultrasonic knife, coblation, and Colorado microneedle. ${ }^{[7]}$

Some surgical and postoperative benefits are attributed to the use of these instruments. Plasma knife and bipolar electrocautery are associated with a significant decrease in operative time compared to cold dissection. Intraoperative blood loss was significantly decreased with plasma knife, compared to cold dissection and bipolar electrocautery $(p<0.05)$. Less postoperative pain was observed with plasma knife compared to bipolar electrocautery while more postoperative pain was observed with both compared to cold dissection $(\mathrm{p}<0.05)$. Postoperative healing time was longer with plasma knife and bipolar electrocautery, compared to cold dissection $(\mathrm{p}<0.05) \cdot{ }^{[12]}$ However, it was well demonstrated in an audit that the use of techniques such as diathermy and coblation has increased rates of postoperative hemorrhage. ${ }^{[13]}$

Despite the advances, none of these surgical techniques or medical devices has helped significantly. As a result of conflicting findings, there is insufficient evidence to support the superiority of one technique over another to reduce post-tonsillectomy bleeding. ${ }^{[2,14]}$ An analysis suggests that of adult patients who undergo a tonsillectomy, $20 \%$ will have a complication. ${ }^{[5]}$ In one study, the rate of primary bleeding (within 24 hours of surgery) ranges from 0.2 to $2.2 \%$ and the rate of secondary bleeding ( $>24$ hours after surgery) ranges from 0.1 to $3 \% .{ }^{[2]}$ One of the latest surgical instruments to come out is called BiZact (Medtronic, Minneapolis, MN, USA). This is a report on our impressions using this device for tonsillectomy.

\section{CASE REPORT}

A summary of the cases can be found in Table 1 .

Case 1- A four-year-old boy presented with snoring, mouth breathing, frequent awakenings, and sweating while sleeping. His physical examination revealed vascularized and mildly retracted ear drums, adenoid hypertrophy fully blocking the choanae, and

\begin{tabular}{|c|c|c|c|c|c|c|c|}
\hline \multicolumn{8}{|c|}{$\begin{array}{c}\text { Table } \mathbf{1} \\
\text { Patients, surgical data, postoperative period }\end{array}$} \\
\hline Patients & Age/Gender & Surgery & $\begin{array}{l}\text { Tonsillectomy } \\
\text { duration (min)* }\end{array}$ & $\begin{array}{c}\text { Estimated } \\
\text { blood loss }(\mathrm{mL})\end{array}$ & $\begin{array}{l}\text { Postoperative } \\
\text { painful time } \\
\text { (days) }^{* *}\end{array}$ & Complications & $\begin{array}{l}\text { Follow-up at the } \\
\text { end of first month }\end{array}$ \\
\hline Case 1 & $4 / \mathrm{M}$ & $\mathrm{T} \& \mathrm{~A}$, tubes & 12 & 2 & 5 & None & Fully recovered \\
\hline Case 2 & $28 / \mathrm{M}$ & Tonsillectomy & 13 & 5 & 12 & $\begin{array}{l}\text { Bleeding on the } \\
\text { POD } 5^{\text {th }} \text { day }\end{array}$ & Fully recovered \\
\hline Case 3 & $35 / \mathrm{M}$ & $\begin{array}{l}\text { Tonsillectomy \& } \\
\text { rhinoplasty }\end{array}$ & 9 & 2 & 10 & None & Fully recovered \\
\hline Case 4 & $4 / F$ & $\begin{array}{l}\mathrm{T} \& \mathrm{~A} \\
\text { myringotomy }\end{array}$ & 9 & 1 & 9 & VPI & $\begin{array}{l}\text { Fully recovered } \\
\text { with a slight } \\
\text { retraction of the } \\
\text { left posterior } \\
\text { tonsillar fold }\end{array}$ \\
\hline
\end{tabular}


a score of 4 on the tonsils of Brodsky scale. ${ }^{[15]}$ A tympanometric study was obtained, demonstrating a bilateral type B tympanogram. Hence, it was decided to proceed with surgery, including bilateral ventilation tube insertions, and adenoidectomy and tonsillectomy.

His surgery was performed under general anesthesia. Tubes were inserted to his ear drums. The adenoidectomy was performed with Coblator (ArthroCare Corporation, Austin, TX, USA), and the tonsillectomy with BiZact. His surgery and the immediate postoperative period were uneventful. He was put on a liquid and soft diet within four hours and discharged the same day. In the following days, he was able to maintain sufficient oral intake and his follow-up examination at three weeks demonstrated a full recovery. A written informed consent was obtained from the legal guardian of the patient.

Case 2- A 28-year-old male patient presented with snoring, frequent apneic episodes during sleep, frequent tonsillar infections, difficulty waking up, and morning fatigue. His physical examination revealed significantly hypertrophic tonsils and Brodsky scale score of 4 . With the diagnosis of hypertrophic tonsils, it was decided to proceed with the tonsillectomy.

His surgery was performed under general anesthesia. The tonsillectomy was performed using BiZact. His surgery and the immediate postoperative period were uneventful. He was put on liquids and a soft diet within four hours and discharged the next day. In the following days, he was able to maintain sufficient oral intake. However, he had bleeding from the middle region of the left tonsillectomy site on the fifth postoperative day which required the surgeons to take him back into the operating room to cauterize the bleeding. He was kept in the hospital for two more days and then discharged. His follow-up examination at 10 days demonstrated a partial recovery, as the tonsillectomy sites were still covered with fibrin and exudate. He was able to maintain sufficient oral intake and active lifestyle. At the four-week follow-up, he was fully recovered. A written informed consent was obtained from the patient.

Case 3- A 35-year-old male patient presented with frequent tonsillar infections and halitosis. In addition, he was bothered by the shape of his nose and described difficulty in breathing through his nose. His oropharyngeal examination revealed moderately hypertrophic tonsils, Brodsky scale score of 3, with deep and wide crypts filled with magma. With the diagnosis of chronic tonsillitis, we decided to proceed with the tonsillectomy.

His surgery was performed under general anesthesia. The first part of the surgery was nasal surgery; septorhinoplasty was performed without any recordable event. The tonsillectomy was performed using BiZact. His surgery and the immediate postoperative period were uneventful. He was put on liquids and a soft diet within four hours and then discharged the following day with the instructions to continue the soft diet for two weeks. In the following days, he was able to maintain sufficient oral intake. His follow-up examination at two weeks demonstrated a partial recovery, as the tonsillectomy sites were still covered with fibrin and exudate. Sixthweek follow-up showed full epithelialization of the tonsillectomy sites. He had no complaints related to the surgical site, such as difficulty swallowing, nasal regurgitation, or voice changes. A written informed consent was obtained from the patient.

Case 4- A four-year-old girl presented with loud snoring and apneic symptoms as described by her parents. She was an obvious mouth breather. Her physical examination was consistent with adenotonsillar hypertrophy and bilateral middle ear effusion, with tonsils of Brodsky scale score of 4. A tympanometric study was obtained, demonstrating a bilateral type $\mathrm{C}$ tympanogram. Upon discussion of her case with her parents, it was decided to undertake surgery to have her adenoids and tonsils removed as well as performing a bilateral myringotomy. The adenoidectomy was performed with Coblator, and the tonsillectomy with BiZact. Her operation went uneventful. The estimated blood loss was around $3 \mathrm{~mL}$.

She was put on a soft diet. She was able to eat and drink, yet she was reportedly unhappy and not compliant. Her pain levels ranged between four and six (out of 10) for the first days. On the fifth postoperative day, her mother sent a picture of her throat, showing significant exudate covering her uvula (Figure 1), indicative of a mucosal injury. On the sixth postoperative day, her mother brought her in when she saw some blood in the patient's mouth. The patient was seen without delay, yet no bleeding was detected. Still, it was decided to keep her in the hospital. She was kept on the same antibiotic regimen (amoxicillin-clavulanate) she had been prescribed for the postoperative period. Her blood tests indicated a slightly increased leucocyte count $(16,200 / \mathrm{uL})$ and C-reactive protein level $(7.81 \mathrm{mg} / \mathrm{L})$. She had sufficient oral intake, yet we administered $20 \mathrm{~mL} /$ hour intravenous isotonic $0.9 \%$ sodium chloride solution to help with hydration.

She was discharged after two uneventful days. She recovered fully in the following weeks, except for a temporary and mild velopharyngeal insufficiency which persisted for a month. By this time, she was able speak clearly and drink fluids without any nasal regurgitation. Her breathing was effortless and reportedly she 


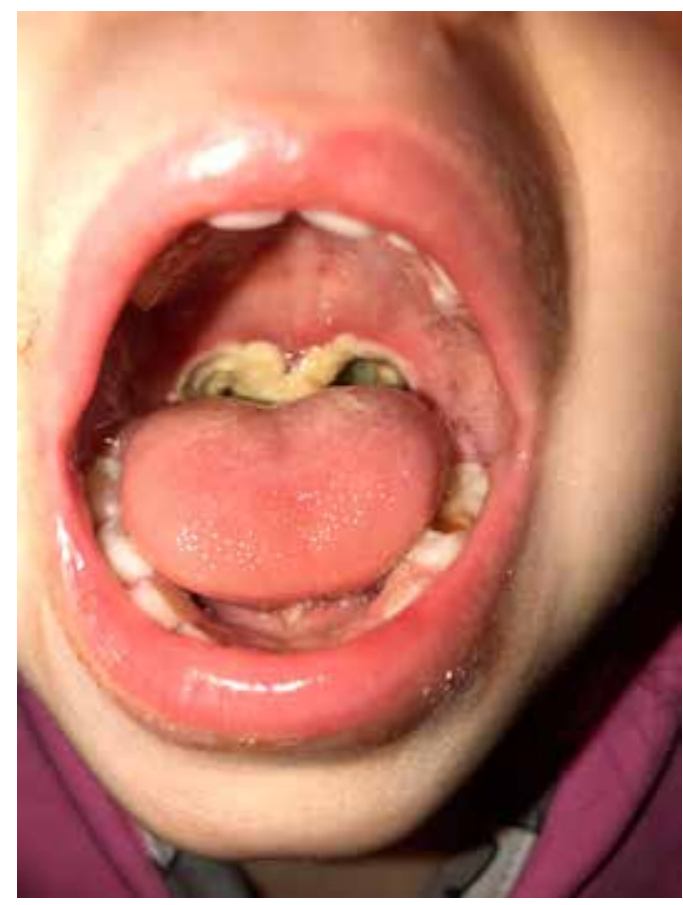

Figure 1. The postoperative fifth day throat view of Case 4.

was sleeping quietly, effortlessly, and without any interruption. Her examination at the end of one month showed fully epithelialized surgical sites with a $2 \mathrm{~mm}$ retraction on the left superior side of the posterior tonsillar fold. A written informed consent was obtained from the legal guardian of the patient.

\section{DISCUSSION}

This study is a collection of cases based on our own experience. Although a very limited number of patients were involved, their surgical and postoperative experiences and our experiences as surgeons are of thought-provoking significance.

LigaSure $^{\circledR}$ is a bipolar "current-carrying" device, which is able to seal vessels. Simultaneously, tissue impedance is measured to control energy application. In this way, only the required energy levels are applied. Therefore, LigaSure ${ }^{\circledR}$ can also be referred as a "softened hot" technique.

In 2005, Lachanas et al. ${ }^{[16]}$ compared the LigaSure ${ }^{\circledR}$ technique with the "cold" steel technique in 200 patients and found significantly less postoperative pain with LigaSure. Postoperative hemorrhage rates were not higher with LigaSure. Based on the LigaSure ${ }^{\circledR}$-scissors, Medtronic introduced a device specifically developed and licensed for tonsillectomies (BiZactTM). The device carries the following properties (Medtronic, 2017):
- $12 \mathrm{~cm}$ shaft for access,

- Curved jaw that follows the shape of tonsil bed,

- Intuitive controls to seal and divide tissue and vessels up to $3 \mathrm{~mm}$ in diameter,

- Ergonomic handle for comfort in both hands.

According to the company brochure (Medtronic, 2017), ${ }^{[17]}$ the BiZact device is an advanced bipolar tissue sealer and divider and is powered by Valleylab ${ }^{\mathrm{TM}}$ energy platforms that:

- Measure impedance of clamped tissue,

- Adjust energy output to create a permanent seal,

- Automatically stop energy delivery when the seal is complete.

In a study comprising 186 children and adults, this new technique is effective and safe with a postoperative hemorrhage rate of $4.3 \%$, similar to rates described by other studies. ${ }^{[18]}$

We, as the authors, would like to share our unquantifiable, yet significant benefits related to surgeries with BiZact. One impression is in regards to its ergonomic design as it fits comfortably in the surgeon's palm. It is easy to understand the concept, with tissue grasping and automatic sealing performed using the measurements made by the processor, and then cutting via the index finger pressing on the trigger button. The tip of the instrument is curved and thus follows the extracapsular plane around the tonsillar tissue. The surgery is relatively bloodless and quick.

We had one patient with bleeding on the fifth postoperative day, which required us to take him to the operating room and cauterize the bleeding. This patient had no further problems. Another patient, a four-yearold girl, had a significant thermal injury on her uvula. This was unexpected, as we thought that we had been careful to avoid any contact with the uvula. However, it is obvious that some mucosal injury had happened through heat transfer.

In conclusion, our impressions regarding BiZact are that the device is ergonomic, helps reduce surgery time and minimize blood loss. Further studies are required in regards to the postoperative morbidity rate.

\section{Declaration of conflicting interests}

The authors declared no conflicts of interest with respect to the authorship and/or publication of this article. 


\section{Funding}

The authors received no financial support for the research and/or authorship of this article.

\section{REFERENCES}

1. Júnior JFN, Hermann DR, Américo RR, Stamm RG, Hirata CW. A brief history of tonsillectomy. Int Arch Otorhinolaryngol 2006;10:314-7.

2. Mitchell RB, Archer SM, Ishman SL, Rosenfeld RM, Coles S, Finestone SA, et al. Clinical Practice Guideline: Tonsillectomy in Children (Update). Otolaryngol Head Neck Surg 2019;160:S1-S42.

3. Chen MM, Roman SA, Sosa JA, Judson BL. Safety of adult tonsillectomy: a population-level analysis of 5968 patients. JAMA Otolaryngol Head Neck Surg 2014;140:197-202.

4. Randall DA, Hoffer ME. Complications of tonsillectomy and adenoidectomy. Otolaryngol Head Neck Surg 1998;118:61-8.

5. Seshamani M, Vogtmann E, Gatwood J, Gibson TB, Scanlon D. Prevalence of complications from adult tonsillectomy and impact on health care expenditures. Otolaryngol Head Neck Surg 2014;150:574-81.

6. Amoils M, Chang KW, Saynina O, Wise PH, Honkanen A. Postoperative Complications in Pediatric Tonsillectomy and Adenoidectomy in Ambulatory vs Inpatient Settings. JAMA Otolaryngol Head Neck Surg 2016;142:344-50.

7. Stuck BA, Götte K, WindfuhrJP, Genzwürker H, Schroten $\mathrm{H}$, Tenenbaum T. Tonsillectomy in children. Dtsch Arztebl Int 2008;105:852-60.

8. Wilson YL, Merer DM, Moscatello AL. Comparison of three common tonsillectomy techniques: a prospective randomized, double-blinded clinical study. Laryngoscope 2009;119:162-70.
9. Hilton M. Tonsillectomy technique--tradition versus technology. Lancet 2004;364:642-3.

10. Walker P, Gillies D. Post-tonsillectomy hemorrhage rates: are they technique-dependent? Otolaryngol Head Neck Surg 2007;136:S27-31.

11. Blanchford H, Lowe D. Cold versus hot tonsillectomy: state of the art and recommendations. ORL J Otorhinolaryngol Relat Spec 2013;75:136-41.

12. Sadikoglu F, Kurtaran H, Ark N, Ugur KS, Yilmaz T, Gozdemir M, et al. Comparing the effectiveness of "plasma knife" tonsillectomy with two well-established tonsillectomy techniques: cold dissection and bipolar electrocautery. A prospective randomized study. Int J Pediatr Otorhinolaryngol 2009;73:1195-8.

13. Lowe D, van der Meulen J; National Prospective Tonsillectomy Audit. Tonsillectomy technique as a risk factor for postoperative haemorrhage. Lancet 2004;364:697702.

14. Pynnonen M, Brinkmeier JV, Thorne MC, Chong LY, Burton MJ. Coblation versus other surgical techniques for tonsillectomy. Cochrane Database Syst Rev 2017;8:CD004619.

15. Brodsky L. Modern assessment of tonsils and adenoids. Pediatr Clin North Am 1989;36:1551-69.

16. Lachanas VA, Prokopakis EP, Bourolias CA, Karatzanis AD, Malandrakis SG, Helidonis ES, et al. Ligasure versus cold knife tonsillectomy. Laryngoscope 2005;115:1591-4.

17. Medtronic. BiZact Brochure, 2017. Available at: https:// www.medtronic.com/content/dam/covidien/library/us/ en/product/vessel-sealing/bizact-tonsillectomy-devicesurgeon-experience-brochure.pdf.

18. Krishnan G, Stepan L, Du C, Padhye V, Bassiouni A, Dharmawardana N, et al. Tonsillectomy using the BiZact: A pilot study in 186 children and adults. Clin Otolaryngol 2019;44:392-6. 